Int. J. Morphol.,

32(2):568-570, 2014.

\title{
A Limit for Antler Length in Captive Marals
}

\author{
Límite del Largo de Cuernos del Ciervo Colorado en Cautiverio
}

Korzhikenova, N."; Sambetbaev, A.*; Iglikov, O.** \& Parés-Casanova, P. M.***

KORZHIKENOVA, N.; SAMBETBAEV, A.; IGLIKOV, O. \& PARÉS-CASANOVA, P. M. A limit for antler length in captive marals. Int. J. Morphol., 32(2):568-570, 2014.

SUMMARY: The main aim of this study was to estimate phenotypic correlations among live weight, withers height, rump height, chest depth, chest width, thoracic girth, body length, hip widths (between iliac tuberosities and between ischial tuberosities) and forelimb cannon perimeter with antler length measured during the growth of marals on a Kazakh farm. The data comprised 18 animals studied during their growth (at 18 months and at 24 months). In maral, the first period of antler productivity takes place at the age of 24 months. This fact should be taken into account in order to select the best animals for antler production, which is the main purpose for farming this species.

KEY WORDS: Phenotypic correlation; Maral; Morphological traits.

\section{INTRODUCTION}

Measuring offspring's growth and development at different ages gives insight into the intensity of growth and development, which can vary as the development of certain body parts depends on genetic and ecological influences.

At the peasant farm "Bagration" in East Kazakhstan, special attention is given to the growth and development of marals to maturity because of the importance given to antler production. The breeding evaluation depends on each animal's usage value. The development grade is obtained by measuring certain body dimensions, so being familiar with correlations between certain production characteristics is very important in breeding-selection work. If the correlation is positive, the improvement of one characteristic will influence the improvement of other mutually positive characteristics, and thereby essentially affect the overall selection success.

The aim of this study was to estimate phenotypic correlations among live weight, withers height, rump height, chest depth, chest width, thoracic girth, body length, hip width (between the iliac tuberosities and between the ischial tuberosities) and forelimb cannon perimeter, with antler length, measured during two periods of growth in Caspian Red Deer or marals, Cervus elaphus sibiricus. The maral is one of the easternmost subspecies of Red deer that is native to areas in Kazakhstan, China, Mongolia and Russia. They are large, strong animals: adult deer can be up to $150 \mathrm{~cm}$ high and weigh up to $260-330 \mathrm{~kg}$ for males and $150-250 \mathrm{~kg}$ for females. At 6 years of age (they have the greatest productivity at 6-12 years of age) the average weight of antlers is $9.9 \mathrm{~kg}(2.0-11.9 \mathrm{~kg})$ and the length of the stem is $64.8 \mathrm{~cm}$ (45-83 cm) (Lunitsyn, 2004). Red deer are highly valued in livestock farming for the presumed healing properties of antlers in young individuals, the so-called "Siberian deer antlers".

\section{MATERIAL AND METHOD}

The data used in this study comprised 18 male marals of Russian and Kazakh origin, managed under similar conditions, and measured during their growth at 18 months and again at 24 months.

Local marals were from the peasant farm "Bagration" (East Kazakhstan region, Ulan area, village of Privolnoye, $50^{\circ} 06^{\prime} \mathrm{N}, 81^{\circ} 32^{\prime} \mathrm{E}$ ). This farm has the status of a pedigree factory for breeding Kazakh white cattle and is also a

\footnotetext{
* Department of Production technology of animal husbandry and fish culture products, Kazakh National Agrarian University, Almaty, Kazakhstan.

** Department of Biology. Semey State University named after Shakarim, Semey, Kazakhstan.

*** Department of Animal Production. University of Lleida, Catalunya, Spain.
} 
breeding farm for Simmental cattle. Maral and horse breeding are additional branches. The farm is located in a dry-steppe zone; the climate is sharp continental with large daily and annual fluctuations in temperature, spanning a range from $-52.5^{\circ} \mathrm{C}$ in winter to $+40^{\circ} \mathrm{C}$ in summer. The average temperature in January is $-16^{\circ} \mathrm{C}$, in July $+20.5^{\circ} \mathrm{C}$. The average annual precipitation is between 180 and $230 \mathrm{~mm}$. Average thickness of the snow cover is $30-40 \mathrm{~cm}$ but it can be $5-80 \mathrm{~cm}$ in separate winters. The soils are dark chestnut and solonetsic. Vegetation: feather grass, fescue, rump, timothy grass, origan, clover, vetch and wormwood.

Russian marals were obtained from the agricultural production cooperative breeding factory "Tenginsky" (Altai Republic, Ongudai area, village of Tenga, 50 $50^{\prime} 34^{\prime \prime} \mathrm{N}$, $\left.85^{\circ} 39^{\prime} 22^{\prime \prime} \mathrm{E}\right)$. This farm has the status of a pedigree factory for breeding the Altai-Sayan breed of marals. The farm is located in a mountain-steppe zone; the climate is sharp continental with large daily and annual fluctuations in temperature, extending from $-49^{\circ} \mathrm{C}$ in winter to $+37.5^{\circ} \mathrm{C}$ in summer. The average temperature in January is $-16^{\circ} \mathrm{C}$, in July $+13^{\circ} \mathrm{C}$. The average annual precipitation is around 300 $\mathrm{mm}$. Average thickness of the snow cover is $30-45 \mathrm{~cm}$, it varies from $6 \mathrm{~cm}$ in valleys to $1.5 \mathrm{~m}$ in mountains. The soils are chernozems, gray forest, sod-podzolic, steppe, mountainmeadow and mountain tundra. Vegetation: larch, karagan, barberry, honeysuckle, kurilian tea, maral root, cowberry, pion herb and chabrets.

The following basic live measurements from the left side of each animal were obtained: live weight, withers height, rump height, chest depth, chest width, thoracic girth, body length, hip width (between iliac tuberosities and between ischial tuberosities), forelimb cannon perimeter and antler length. For linear measurements, three instruments

Table I. Phenotypic correlations among live weight, withers height, rump height, chest depth, chest width, thoracic girth, body length, hip widths (between iliac tuberosities and between ischial tuberosities), forelimb cannon perimeter and antler length, with antler length measured during both periods of maral growth $(n=18$, the same animals at 18 and 24 months of age). Only significant $\mathrm{p}$-values $(<0.05)$ appear.

\begin{tabular}{lcccr}
\hline \multirow{2}{*}{ Phenoty pic correlations } & \multicolumn{2}{c}{$\mathbf{1 8}$ months } & \multicolumn{2}{c}{ 24 months } \\
\cline { 2 - 5 } & $\mathbf{. r}_{\mathrm{s}}$ & $\mathbf{P}$ & $\mathbf{. r}_{\mathrm{s}}$ & $\mathbf{P}$ \\
\hline Body weight & 0.697 & 0.001 & & \\
Withers height & 0.797 & 0.000 & -0.510 & 0.030 \\
Rump height & 0.820 & 0.000 & -0.613 & 0.007 \\
Chest depth & 0.930 & 0.000 & -0.545 & 0.019 \\
Chest width & 0.882 & 0.000 & -0.487 & 0.040 \\
Thoracic girth & 0.857 & 0.000 & & 0.283 \\
Body length & 0.910 & 0.000 & & 0.144 \\
Hip width (iliac tuberosities) & 0.951 & 0.000 & -0.588 & 0.010 \\
Hip width (ischial tuberosities) & 0.701 & 0.001 & & \\
Cannon perimeter & 0.746 & 0.000 & & \\
\hline
\end{tabular}

were used: measuring stick, measuring compass and ruler (tape). The measurements taken by stick were: wither height, rump height, chest depth and width, and body length. The measurements taken by ruler were: thoracic girth, forelimb cannon perimeter and antler length. The measurements taken by compass were: hip width between iliac tuberosities and between ischial tuberosities. Each measurement was taken once, always by the first author. Animals were measured in vivo using a subjection catch, therefore, no ethical permission was needed.

A Hotelling's test was applied in order to determine if the two age periods presented differences according to all parameters. A linear model to fit a quadratic regression (straight line $\mathrm{y}=\mathrm{ax}+\mathrm{b}$ ) was used, with Reduced Major Axis (RMA) as the algorithm. RMA tries to minimize the errors in both $\mathrm{x}$ and $\mathrm{y}$. With the linear model, this allowed us to fit data to the 'allometric' function $\mathrm{y}=10 \mathrm{bxa}$. As for withers height, the a values were larger than 1 , indicating that a straight-line ('isometric') fit would not be possible; a polynomial fit was then attempted. The polynomial was used for all animals together in order to determine the antlers growth to the fifth order $(y=a 5 \times 5+a 4 \times 4+a 3 \times 3$ $+\mathrm{a} 2 \times 2+\mathrm{a} 1 \mathrm{x}+\mathrm{a} 0)$, as it presented the lowest chi-squared value (the chi-squared value is a measure of fitting error - larger values mean poorer fit). The Akaike Information Criterion (AIC), which represents a penalty for the number of terms, was finally calculated. The AIC should be as low as possible to maximize fit. As both age periods appeared differentiated, they were treated separately. In order to avoid normality problems, data were log-transformed (base 10) for all analyses. Statistical treatment was done with PAST (Hammer et al., 2001).

\section{RESULTS}

Hotelling's test showed differences between both age groups $(\mathrm{t} 2=4176.6, \mathrm{p}<0.001)$. Phenotypic correlations of the studied parameters with antler length according to age, are shown in Table I. Antler length showed correlation $(\mathrm{p}<0.05)$ with all parameters for animals aged 18 months. Negative correlations $(\mathrm{p}<0.05)$ appeared with most parameters for animals aged 24 months. For body weight the correlation was not significant. Withers height can be considered a "size" parameter. It followed the quadratic regression with antler length: $\mathrm{Y}=3.462 \mathrm{x}-5.680$, $\mathrm{r} 2=0.636(\mathrm{p}<0.001)$ and $\mathrm{Y}=-6.535 \mathrm{x}+15.571$, $\mathrm{r} 2=0.260(\mathrm{p}<0.05)$ for animals aged 18 and 24 months, respectively, showing in the latter a clear 
negative slope. The polynomial fit to the fifth order for all animals, which presented the best fit $(\mathrm{X} 2=0.113)$ of all polynomials, clearly showed the limit on antler length according to withers height and according to age (Fig. 1).

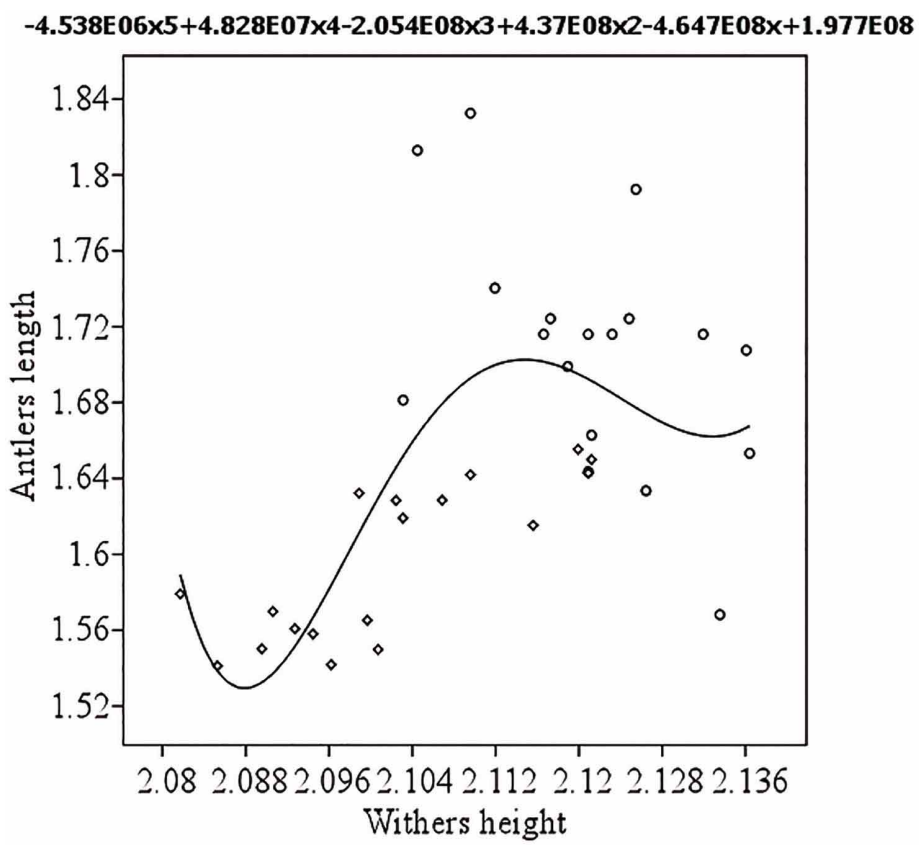

Fig. 1. Polynomial fit to the fifth order for all animals fit $(n=18)$ between withers height and antler length. X2=0.113.

\section{DISCUSSION}

Behaviour studies of ruminants show that horn-like organs can function as weapons, as display organs or rank symbols, as shields to catch and neutralize attacks by conspecifics, and as determinants of dominant rank (Geist, 1968). They are of great importance to the reproductive success of the individual. Whatever their function, for deer in general, species with a larger body size have antlers that are more than proportionately larger, a consequence of allometry, or differential growth rates of body size and antler size during development (Gould, 1974). So it is absolutely congruent with the obtained results that larger (but not necessarily heavier) males present larger antlers, especially in 18 month old animals, limiting antler growth according to age. This fact should be taken into account in order to select the best animals for antler production.

\section{ACKNOWLEDGEMENTS}

We wish to thank all the workers at the deer-farm "Bagration", who have always been ready to co-operate and help in any necessary way on occasions of field research.
KORZHIKENOVA, N.; SAMBETBAEV, A.; IGLIKOV, O. \& PARÉS-CASANOVA, P. M. Límite del largo de cuernos del ciervo colorado en cautiverio. Int. J. Morphol., 32(2):568-570, 2014.

RESUMEN: El objetivo de este estudio fue estimar en ciervos colorados de una granja de Kazajstán, las correlaciones fenotípicas entre el peso vivo, altura a la cruz, la profundidad del pecho, ancho de pecho, circunferencia torácica, longitud del cuerpo, ancho de cadera (entre tuberosidades ilíacas e isquiáticas) y perímetro del miembro anterior, con el largo de cuernos medido durante su crecimiento. Los datos de este estudio comprendieron 18 animales durante su crecimiento (entre los 18 y 24 meses). En el ciervo colorado el período inicial de la productividad de cuernos tiene lugar a los de 24 meses de edad. Este hecho se debe tener en cuenta para seleccionar los mejores animales para la producción de cuernos, objetivo principal para la crianza de esta especie.

PALABRAS CLAVE: Correlación fenotípica; Maral; Rasgos morfológicos.

\section{REFERENCES}

Geist, V. Horn-like structures as rank symbols, guards, and weapons. Nature, 220(5169):813-4, 1968.

Gould, S. J. The Origin and Function of 'Bizarre' Structures: Antler Size and Skull Size in the 'Irish Elk,' Megaloceros giganteu. Evolution, 28(2):191-220, 1974.

Hammer, Ø.; Harper, D. A. T. \& Ryan, P. D. PAST: Paleontological Statistics Software Package for Education and Data Analysis. Palaeontologia Electronica 4(1):1-9, 2001.

Lunitsyn, V. G. Antler deer breeding of Russia. Barnaul, Russian Academy of Agricultural Sciences, Siberian branch of the Russian Research Institute of antler deer breeding, 2004. pp.151-9.

Correspondence to:

Pere M. Parés-Casanova PhD

Associate Professor

Dep. of Animal Production

University of Lleida

Avda. Rovira Roure, 191

25198 Lleida

SPAIN

Email: peremiquelp@prodan.udl.cat

Received: 14-04-2013

Accepted: 09-02-2014 